\title{
Miskin dan Kaya Dalam Injil Lukas dan Teologi Pembebasan
}

\author{
Vasika Hananti ${ }^{1}$ \& Bambang Subandrijo ${ }^{2}$ \\ Sekolah Tinggi Teologi Sriwijaya ${ }^{1}$, Sekolah Tinggi Filsafat Theologi Jakarta² \\ hanantivasika@yahoo.com
}

\begin{abstract}
Harvey J. Sindima observed Liberation Theology as it flourished in Latin America, Africa, Asia, and the United States. The social situation in that society has some similarities in Luke's community. According to Philip Francis Esler's research, Luke's theology seeks to answer the social situation in Luke's community, especially regarding the relationship between the rich and the poor. This study aims to review Sindima's review of Liberation Theology based on Philip Francis Esler's thoughts on the relationship between rich and poor in Luke's Gospel. In Sindima's writings, the involvement of the rich has not been found as an effort to minimize the suffering of the poor. In this study, the author uses an analytical method. The result is that the good news for the poor in Liberation Theology is in line with the good news in Luke's Gospel. Moreover, in Luke's Gospel the liberation of the poor is not only the responsibility of the poor themselves as in the Theology of Liberation in Sindima's description, but also the responsibility of the rich as part of a sharing community.
\end{abstract}

Keywords: poor, rich, Gospel of Luke, liberation theology

Abstrak: Harvey J. Sindima mengamati Teologi Pembebasan yang berkembang di Amerika Latin, Afrika, Asia, dan Amerika Serikat. Situasi sosial dalam masyarakat tersebut memiliki beberapa kesamaan dalam komunitas Lukas. Menurut penelitian Philip Francis Esler, teologi Lukas berupaya menjawab situasi sosial dalam komunitas Lukas, terutama menyangkut hubungan orang kaya dan orang miskin. Penelitian ini bertujuan untuk meninjau uraian Sindima tentang Teologi Pembebasan berdasarkan pemikiran Philip Francis Esler berkenaan dengan hubungan orang miskin dan kaya dalam Injil Lukas. Dalam tulisan Sindima masih belum ditemukan keterlibatan orang kaya sebagai upaya meminimalisir penderitaan orang miskin. Dalam penelitian ini, penulis menggunakan metode analitis. Hasil tinjauan ini adalah bahwa kabar baik bagi orang miskin dalam Teologi Pembebasan sejalan dengan pemberitaan kabar baik dalam Injil Lukas. Lebih dari itu, dalam Injil Lukas pembebasan terhadap orang miskin bukan hanya menjadi tanggung jawab orang miskin itu sendiri sebagaimana dalam Teologi Pembebasan dalam uraian Sindima, tetapi juga merupakan tanggung jawab orang kaya sebagai bagian dari komunitas yang saling berbagi.

Kata Kunci: miskin, kaya, Injil Lukas, teologi pembebasan

Article History

\begin{tabular}{|l|l|l}
\hline Submitted: 9 Juni 2021 & Revised: 23 Juli 2021 & Accepted: 28 Juli 2021
\end{tabular}

\section{PENDAHULUAN}

Pemikiran Teologi Pembebasan berangkat dari pergumulan dalam konteks. Lebih tepatnya, Teologi Pembebasan bertitik tolak dari situasi masyarakat di Amerika Latin yang mengalami kemiskinan (Grenz \& Olson, 1992). Namun kemudian, Teologi Pembebasan tidak hanya muncul di Amerika Latin, melainkan juga di Asia dan Afrika (Yewangoe, 1995).

Banyak teolog yang telah meninjau, mengevaluasi ataupun mengkritisi Teologi Pembebasan. Ada yang meninjau dogma Teologi Pembebasan, seperti Natali yang meninjau pandangan Gustavo Gutierrez terutama mengenai doktrin gereja yang 
ternyata memengaruhi gereja-gereja tradisional di Indonesia (Natali, 2000). Selain itu, ada juga yang mengevaluasi mengenai metode yang digunakan Gutierrez. Fajar Gumelar bersama dengan Hengki Wijaya mengungkapkan bahwa Teologi Pembebasan merupakan model teologi yang berorientasi pada praksis untuk melakukan pembebasan bagi kaum marginal, miskin dan tertindas. Namun, mereka menganggap teologi ini lebih mirip ideologi destruktif karena dipengaruhi oleh Marxisme (Gumelar \& Wijaya, 2019). Pemikiran yang serupa juga diutarakan oleh Christian O. Uchegbue dan Zoltan Zegel yang lebih melihat pengaruh Marxisme terhadap Teologi Pembebasan (Uchegbue, 2011; Vegel, 2018). Mateus Mali juga mengatakan bahwa teologi menurut Gutierrez merupakan suatu refleksi kritis yang menjawab tantangan zaman dengan permasalahan sosialnya, terutama kemiskinan (Mali, 2016). Agus Kriswanto pun meneliti metode Teologi Pembebasan yang menurutnya analisis terhadap hermeneutika Teologi Pembebasan harus melihat dasar filosofisnya agar dapat menilainya dengan adil dan proporsional (Kriswanto, 2020). Karena itu kritik terhadap pendekatan hermeneutika Teologi Pembebasan tidak tepat jika mempertentangkan antara eksegesis dan eisegesis, melainkan harus melampaui pertentangan tersebut.

Harvey J. Sindima juga mengamati Teologi Pembebasan dalam masyarakat Amerika Latin, Afrika, Asia dan Amerika Serikat, sebenarnya tidak hanya soal ekonomi, tetapi juga menyangkut soal keterasingan dalam hal ras dan budaya (Sindima, 2008). Jadi, kemiskinan yang melanda orang-orang miskin tidak hanya karena kekurangan pangan maupun tempat tinggal, tetapi mereka juga mengalami penindasan dalam hal ras dan budaya akibat adanya stratifikasi sosial dalam masyarakat.

Situasi sosial dalam masyarakat Amerika Latin, Afrika, Asia dan Amerika Serikat, juga memiliki beberapa kesamaan dalam komunitas Lukas. Pengamatan terhadap komunitas Lukas dengan teliti dilakukan oleh Philip Francis Esler. Esler meneliti bahwa komunitas Lukas terdiri dari dua spektrum kelas yang terdapat jurang pemisah yang besar. Dengan demikian, Lukas menempatkan teologinya atas dasar motif sosial dan politik. Upaya penelitian Esler ini adalah untuk melihat bagaimana kedudukan orang-orang miskin dan bagaimana peran orang-orang kaya dalam rangka mewujudkan pembebasan bagi orang-orang miskin (Esler, 1987)

Melalui tulisan Sindima ditemukan bahwa Teologi Pembebasan (1980-an 1990-an) berorientasi pada penindasan terhadap orang-orang miskin. Bahkan Sindima melihat bahwa penindasan tersebut tidak hanya masalah ekonomi, tetapi juga dalam 
hal ras dan budaya. Berdasarkan uraian Sindima didapatkan gambaran bahwa dalam Teologi Pembebasan masih minim memunculkan keterlibatan orang-orang kaya dalam upaya meminimalisir penderitaan orang-orang miskin. Dengan demikian, penulis tertarik untuk meninjau pemikiran Sindima tentang Teologi Pembebasan berdasarkan pemikiran Esler tentang teologi Lukas, khususnya mengenai tanggung jawab orang kaya terhadap orang miskin. Penelitian ini diupayakan untuk melihat wawasan dalam teologi Lukas yang memperlihatkan adanya upaya keterlibatan orangorang kaya membantu orang-orang miskin.

Hasil penelitian ini adalah bahwa kabar baik bagi orang miskin dalam Teologi Pembebasan menurut pemikiran Sindima, sejalan dengan pemberitaan kabar baik dalam Injil Lukas menurut pemikiran Esler. Lebih dari itu, menurut Esler, dalam Injil Lukas pembebasan terhadap orang miskin bukan hanya menjadi tanggung jawab orang miskin itu sendiri, melainkan juga merupakan tanggung jawab orang kaya sebagai bagian dari komunitas yang saling berbagi. Hal ini berbeda dari Teologi Pembebasan yang diuraikan oleh Sindima yang belum memperlihatkan adanya keterlibatan orang kaya terhadap orang miskin. Dengan begitu, teologi Lukas berdasarkan Esler dapat menjadi cakrawala berteologi dalam menghadapi masalah kemiskinan dengan menyentuh kedua spektrum kelas, yaitu orang kaya dan orang miskin.

\section{METODE}

Untuk menyelesaikan proyek ini, Penulis menggunakan metode analitis (Kothari, 2004). Pertama-tama, Penulis menguraikan pemikiran Sindima mengenai Tologi Pembebasan. Kemudian, Penulis memaparkan penjelasan Esler berkenaan dengan keterlibatan orang kaya dalam mengatasi kemiskinan. Selanjutnya, Penulis melakukan tinjauan kritis terhadap pemikiran Sindima berdasarkan pemikiran Esler.

\section{HASIL DAN PEMBAHASAN}

\section{Orang Kaya dan Miskin dalam Teologi Pembebasan Menurut Pemikiran Harvey}

\section{J. Sindima}

Harvey J. Sindima adalah seorang teolog dari Malawi. Sindima melihat bahwa perhatian utama Teologi Pembebasan hanyalah pada hal ekonomi, sebab dalam pandangan Teologi Pembebasan, ekonomi merupakan masalah utama kemiskinan. $\mathrm{Hal}$ ini dinyatakan dalam tulisannya yang menyinggung tentang konferensi Medellin dan Puebla. Sindima mengatakan bahwa "Medellin and Puebla spoke of the poor more 
in economic terms, that is, the social and economically poor" (Sindima, 2008). Banyak aktivis politik dan beberapa teolog melihat bahwa penindasan Amerindian, orang keturunan Afrika, dan perempuan pada dasarnya adalah masalah ekonomi. Sindima melihat ada kelalaian dalam Teologi Pembebasan, yaitu mengenai masyarakat pribumi, ras, keterasingan budaya dan perempuan. Menurut Sindima, kelalaian ini menyebabkan kebungkaman terhadap masalah-masalah masyarakat pribumi, ras, keterasingan budaya dan perempuan dalam teologi pembebasan (Sindima, 2008). Oleh karena itu, Sindima ingin mengungkapkan perlunya perhatian pada soal masyarakat pribumi, ras dan perempuan terkait dengan kemiskinan. Persoalan ini memperlihatkan jurang yang tajam antara orang kaya dan orang miskin. Orang kaya sebagai orang dari ras yang terhormat, sedangkan orang miskin adalah orang dari ras rendah.

Penderitaan masyarakat Amerindian yang oleh karena ras misalnya berkenaan dengan hak kepemilikan tanah. Masyarakat Amerindian pada umumnya tidak memiliki tanah. Kasus di Brazil pada tahun 2003, dari populasi lebih dari 184 juta, hanya 340 yang memiliki tanah dan menguasai 117 hektar tanah. Tetapi orang-orang Amerindian hanya mengolah 11 persen darinya. Masalah tanah di Brazil sebenarnya sudah sejak tahun 1850 ketika disahkannya Lei de Terras (Hukum Tanah) untuk mengatur kepemilikan. Undang-undang tersebut melarang orang yang diperbudak dan keturunan mereka memiliki tanah karena mereka bukan orang Brazil. Undang-undang tersebut menyebabkan pemberontakan dari orang kulit hitam. Karena khawatir akan pemberontakan tersebut, orang kulit putih menggunakan Lei de Terras untuk menaikkan harga tanah (Sindima, 2008). Hal tersebut menggambarkan bahwa masyarakat Amerindian berada pada kelas bawah atau sebagai orang yang tidak berpunya tanah dan miskin. Sedangkan orang-orang kulit putih menempati kedudukan sebagai orang yang berpunya tanah dan kaya. Terdapat jurang yang lebar antara masyarakat Amerindian (sebagai orang miskin) dan orang orang-orang kulit putih (sebagai orang kaya).

Jurang antara orang kaya (orang kulit putih) dengan orang miskin (orang Amerindian) diperlihatkan juga oleh keberadaan Gereja Katolik pada era kolonial yang tidak dapat berpihak secara seimbang di antara orang kaya dan miskin. Gereja Katolik justru mendukung sistem semi-feodal yang merampas tanah orang-orang Amerindian. Gereja Katolik lebih berpihak kepada si penindas (Grenz \& Olson, 1992). Di era kolonial tersebut, otoritas Gereja Katolik berada bersama dengan para pemimpin sipil dan militer. Orang-orang Amerindian dan mestizo (ras campuran) terpaksa melayani 
kepentingan para pemilik tanah, pejabat sipil, dan pejabat gerejawi. Dengan demikian, Sindima dapat memberikan ulasan bahwa masyarakat pribumi tidak hanya dilupakan dalam literatur pembebasan dan lingkungan gereja, tetapi juga dalam tulisan-tulisan non-teologis, kehidupan sosial dan politik. Masyarakat pribumi ini adalah orang-orang yang tidak terlihat, sebab mereka adalah orang-orang yang berada di tingkat paling bawah dalam masyarakat (Sindima, 2008).

Pada tahun 1888, Brazil menghapus perbudakan. Namun kenyataannya, tidak ada orang-orang kulit hitam yang duduk dalam pemerintahan pusat dan organisasi nasional, meskipun Brazil memiliki populasi orang kulit hitam terbesar di luar Afrika. Menurut analisis Sindima, hal ini karena faktor ras. Jika bukan karena ras, maka negara-negara seperti Bahia dan Salvador pasti sudah memiliki walikota dan gubernur Afrika-Brazil. Tidak ada orang kulit hitam yang duduk di pemerintahan di Brazil sampai pada masa kepresidenan Luiz Inacio Lula da Silva (Sindima, 2008). Dengan demikian, sampai pada tahun 1888 belum ada upaya yang berhasil untuk menekan jurang antara orang kaya dan miskin.

Jurang yang lebar antara yang kaya dan yang miskin juga terlihat dalam bidang pendidikan. Hanya sekitar 3 persen dari 1,4 juta anak-anak orang kulit hitam pardo yang diterima di universitas di Brazil. Selain itu, karena Brazil tidak memiliki cukup tempat di universitas negeri, maka Brazil menyelenggarakan ujian masuk perguruan tinggi nasional. Dengan kondisi ini, siswa kulit hitam tidak mendapat nilai tinggi pada ujian karena mereka memiliki dua tahun lebih sedikit sekolah daripada anak-anak kulit putih (Sindima, 2008).

Namun kemudian, Sindima melihat bahwa Teologi Pembebasan mulai berbicara tentang ras yang merupakan kritik dari orang-orang keturunan Afrika di Karabia dan Amerika Utara (sekitar tahun 1985). Di Brazil, para teolog seperti Mauro Batsta dan lainnya, mengangkat masalah ras dalam Gereja Katolik. Mereka menerjemahkan ideologi branqueamento yang mendorong orang-orang keturunan Afrika untuk menolak Blackness mereka. Namun, Gereja Katolik yang terdiri dari orangorang kaya tidak hanya diam tentang masalah ini, tetapi juga mengabadikan branqueamento (Sindima, 2008). Artinya, orang-orang kaya tidak mau terlibat untuk menangani kesenjangan.

Sindima tidak hanya melihat adanya kesadaran penderitaan akibat ras. Mulai tahun 1990-an, Sindima melihat munculnya kesadaran tentang isu-isu penindasan terhadap perempuan di bidang kehidupan politik dan ekonomi. Wanita di Amerika Latin setuju dengan para teolog pembebasan bahwa akar utama penindasan kaum 
perempuan adalah sistem patriarki (Sindima, 2008). Selain wanita, anak-anak juga merupakan korban dari penindasan. Di Brazil, terdapat lebih 35 juta anak yang ditinggalkan oleh orang tua mereka dan hidup dalam kesengsaraan yang parah (Sindima, 2008).

Selain itu, dalam pandangan Sindima, penindasan yang paling sedikit disebutkan dalam Teologi Pembebasan adalah keterasingan budaya. Hal ini karena ada pengaruh dari Marxisme (Berghoef \& DeKoster, 1984; Schwarz, 2005). Dalam analisis Marxis, budaya dikorbankan untuk kepentingan sosial, ekonomi dan politik. Marx tidak melihat nilai-nilai dalam budaya dan meminimalkan budaya. Dominasi ekonomi erat kaitannya dengan keterasingan budaya. Misalnya, dapat dilihat dari fakta bahwa kapitalis borjuis menghasilkan mentalitas dan gaya hidup borjuis, yaitu seorang yang egois dan mencari kesenangan hidup. Bahkan Marxis dan simpatisan mereka berpendapat bahwa konflik antara perjuangan etnis dan kelas dapat membahayakan pembebasan rakyat secara total (Sindima, 2008).

Kemudian, tema yang lebih mendapat perhatian dalam Teologi Pembebasan adalah spiritualitas. Sindima mengemukakan bahwa literatur pembebasan tahun 1980 an dan 1990-an didominasi oleh tulisan-tulisan tentang spiritualitas. Namun, bagi pembaca di luar Amerika Latin, literatur ini tersembunyi bagi mereka. Literatur-literatur tentang spiritiualitas sebagian besar belum diterjemahkan, dan takut dibayangi oleh kritik terhadap ide-ide Marxis, analisis sosial, dan literatur politik, yang sering dikaitkan dengan Teologi Pembebasan. Para Teolog Pembebasan menganggap bahwa spiritualitas harus dianggap serius karena merupakan cara hidup orang Kristen. Gutierrez, Boff, Galilea, Sobrino dan Frei Betto (Brazil) adalah beberapa Teolog Pembebasan yang telah menulis tentang spiritualitas. Setelah memasuki dunia orang miskin, para teolog ini belajar bahwa spiritualitaslah yang memberikan keberanian dan kekuatan kepada orang miskin untuk terus berjuang meskipun mereka menderita (Sindima, 2008).

Para penulis tentang spiritualitas bergumul dengan pertanyaan tentang komitmen terhadap penderitaan orang miskin. Di Amerika Latin ada dua jenis kepekaan religius, yaitu kekristen popular dan yang resmi. Kekristenan popular adalah hasil dari pengaruh tiga tradisi agama: Kristen, Afrika dan tradisi Amerindian. Ketiga pengaruh agama ini tidak dapat dipisahkan dalam agama Kristen Amerika Latin. Sedangkan agama resmi terdiri dari keyakinan dan norma yang ditentukan dari sebuah lembaga yang diumumkan dan dipantau oleh sekelompok spesialis agama. Gereja resmi menolak religiusitas popular karena pengaruh Afrika dan Amerindian. Religiusitas 
popular dianggap sebagai hal yang memalukan. Sementara agama resmi memiliki pemahaman yang lebih mendalam tentang pesan Kristen (Sindima, 2008).

Religiusitas populer berfokus pada pengabdian, pemujaan terhadap gambargambar suci, dan itu ritualistik. Agama populer adalah agama subkultur: orang miskin dan tertindas. Gereja resmi tidak mendukung agama populer seperti yang dapat dicatat dari suara uskup yang bertemu dengan seorang Madellin. Meskipun para uskup mendukung proyek pembebasan, meminta gereja untuk memilih orang miskin, namun mereka tidak sepenuhnya mendukung religiusitas orang miskin (Sindima, 2008).

Untuk waktu yang lama, para teolog pembebasan juga meremehkan religiusitas populer. Namun kemudian telah berubah karena tekanan pada penghormatan terhadap orang miskin. Para teolog pembebasan sekarang mengatakan orang miskin harus memiliki martabat karena mereka adalah agen sejarah pembebasan mereka sendiri. Untuk menegaskan orang-orang ini, Teologi Pembebasan mencari unsur-unsur positif dari spiritualitas mereka.

Teologi Pembebasan terus menjadi kekuatan di Gereja Amerika Latin. Teologi Pembebasan telah sangat membantu Gereja dalam mendapatkan identitas baru di Amerika Latin. Dengan temanya "Preferential for the Poor," Teologi Pembebasan membawa pada peningkatan keanggotaan Gereja. Banyak kemurnian muncul di antara orang miskin di berbagai keuskupan. Komunitas gerejawi terus membaca Alkitab. Sebelumnya di seluruh tradisi Katolik, kaum awam tidak didorong untuk membaca Alkitab. Namun kemudian, Carlos Mesters merintis untuk membuat Alkitab agar dapat diakses oleh orang miskin (Sindima, 2008). Dalam hal metode, teologi pembebasan menciptakan motode baru, yaitu teologi kontekstual yang mencerminkan perjuangan dan aspirasi lokal. Dalam Teologi Pembebasan, para pengusung era baru bukanlah proletariat industry Marx, melainkan kaum miskin dan yang tidak bertanah (Sindima, 2008).

\section{Orang Kaya dan Miskin dalam Lukas Menurut Philip Francis Esler}

Esler dalam penelitiannya mencoba untuk menilai sejauh mana ciri-ciri teologi Lukas dimotivasi dan dipengaruhi oleh batasan sosial dan politik yang dialami oleh komunitasnya. Fokus utama Esler adalah pada sikap Lukas terhadap kemiskinan dan kekayaan dalam kehidupan Kristen (Esler, 1987).

Esler mengganggap bahwa salah satu sumber dari Lukas adalah Markus. Karena itu, la melihat ada beberapa bagian dalam Lukas yang mengungkapkan intensifikasi sikap terhadap kekayaan dan kemiskinan yang ada dalam Markus. Salah 
satu bagian yang penting adalah khotbah pertama Yesus di Sinagoge, di Nazaret. Dalam Markus, kejadian ini terjadi dalam pelayanan publik Yesus (Mrk. 6:1-6), tetapi Lukas telah meletakkannya ke awal pelayanan Yesus (Luk. 4:16-30). Pemindahan kisah Yesus berkhotbah di Sinagoge di Nazaret ke bagian awal pelayanan Yesus menjadi penekanan versi Lukas untuk menempatkan orang miskin sebagai penerima kabar baik (Esler, 1987).

Dalam menganalisis siapa orang-orang kaya dan miskin dalam Lukas, Esler mencoba untuk menghubungkan sikap Lukas pada kekayaan dan kemiskinan dengan realitas kehidupan di kota Helenistik di Romawi Timur menjelang akhir abad pertama Masehi. Dalam masyarakat Romawi ada tingkatan strata sosial. Orang-orang yang berada pada strata sosial atas adalah para elit bangsawan dan elit kaya, sedangkan yang paling bawah adalah orang-orang miskin. Para elit bangsawan ini, misalnya terdiri dari anggota ordines, baik itu senator, penunggang kuda atau decurions (Esler, 1987). Sedangkan kelas orang-orang miskin terdiri dari para pedagang, para pengrajin, orang-orang yang terlibat dalam industri jasa (seperti pengangkut barang), para pekerja harian, dan orang-orang yang benar-benar miskin yang tidak memiliki pekerjaan seperti orang buta, orang cacat, atau orang yang memiliki gangguan mental, dan para budak (Esler, 1987). Dari kedua kelas ini, terlihat jelas jurang pemisah yang sangat jauh antara elit bangsawan atau orang kaya dan kelas orang miskin.

Orang-orang miskin yang tinggal di kota Helenistik di Timur Romawi memiliki dua kebutuhan pokok, yaitu pangan dan papan. Orang miskin harus memastikan bahwa mereka memiliki cukup gandum dan sedikit minyak zaitun untuk memasak dan penerangan. Masalah bagi pekerja harian adalah bahwa mereka harus selalu mencari pekerjaan setiap hari. Gagal mendapatkan pekerjaan berarti bahaya kelaparan mengancam dirinya dan keluarganya. Oleh karena itu, bagi kaum miskin di kota, setiap hari harus berjuang untuk mendapatkan makanan (Esler, 1987).

Berdasarkan analisis D. van Berchem, Esler menuliskan bahwa Roma memang memiliki sistem distribusi jagung yang disediakan secara gratis. Namun, distribusi itu terbatas pada sejumlah warga negara Romawi saja. Penduduk yang bukan Roma tidak bisa memperolehnya. Kadang-kadang warga Roma yang kaya membagikan jagung secara gratis. Namun, mereka hanya mengharapkan agar mendapat kehormatan. Hal itu pun hanya dilakukan dalam sekali waktu saja (Esler, 1987). Jadi, faktanya ada banyak orang yang mengalami kelaparan di kota-kota kekaisaran Romawi (Esler, 1987). 
Selanjutnya, kebutuhan kedua dari kaum miskin di kota adalah tempat tinggal. Banyak orang yang mengadopsi cara hidup tunawisma di kota-kota kekaisaran Romawi. Mereka adalah orang-orang yang tidak memiliki pendapatan apapun (kecuali mengemis). Ada juga yang tinggal di gubuk kecil. Mereka adalah orang-orang yang mempunyai sedikit penghasilan. Ada juga yang menyewa rumah. Namun, rumah orang miskin berisiko runtuh sebab bangunannya tidak baik. Rumah yang digunakan oleh orang miskin penuh sesak, gelap dan tidak sehat (Esler, 1987).

Dari keterangan tersebut dapat diketahui bahwa kondisi orang-orang miskin di kota Helenistik di Timur Romawi sangat memprihatinkan. Tidak hanya soal ekonomi mereka kekurangan, tetapi juga masalah mereka meliputi kesehatan. Jadi, bagi mereka hidup adalah suatu hal yang sangat suram.

Mengingat latar sosial di kota-kota Helenistik yang memperlihatkan adanya stratifikasi sosial, Esler memberikan perhatian dalam kitab Lukas pada Lukas 4:16-30. Yesus menyebut janda dari Sarfat dan Naaman orang Siria sebagai contoh orang nonYahudi yang mengalami cinta kasih dari Allah Israel. Esler melihat bahwa janda dan Naaman mewakili spektrum sosial yang ekstrem: janda merupakan salah satu kaum miskin di kota yang dalam ambang kematian karena kelaparan (1 Raj. 17,12), dan Naaman merupakan komandan tentara yang kaya dan berkuasa dari raja Aram (2 Raj. 5:1-5). Pemilihan Lukas dari dua karakter ini tidak hanya terkait dengan Injil terbuka untuk orang non Yahudi, tetapi Lukas menekankan bahwa Yesus mengesahkan kehadiran dalam komunitas Kristen baik orang kaya maupun orang miskin (Esler, 1987). Jadi, Esler menyimpulkan bahwa komunitas Lukas mencakup individu-individu dari lapisan atas dan bawah masyarakat Helenistik, tetapi Injilnya mengangkat orangorang miskin ke posisi yang lebih unggul. Dalam Injil Lukas, Yesus berjanji untuk meringankan kekurangan fisik yang diderita oleh para pengemis, orang buta, orang lumpuh, orang yang dipenjarakan dan sebagainya, namun juga tanpa mengabaikan aspek spiritual dari keselamatan (Esler, 1987).

Komunitas yang terdiri dari orang kaya dibuktikan oleh Esler pertama-tama dengan melihat adanya gaya sastra yang tinggi dari bagian-bagian Lukas-Kisah Para Rasul terutama dari prolog (Luk. 1:1-4) dan deskripsi tentang pelayaran Paulus ke Roma dan kapal yang karam di Kisah Para Rasul 27. Dari teks-teks tersebut, menyiratkan bahwa pengarangnya berasal dari segmen atas masyarakat YunaniRomawi. Kedua, Lukas memberikan perhatian pada orang-orang yang bertobat dengan status ekonomi dan kekuasaan politik yang lebih tinggi (Luk. 7:1-10; 2:47; Kis. 10:1-dst.) (Kim, 1998). Selain itu, ada juga bagian-bagian dalam Injil Lukas di mana 
Yesus memperingatkan orang kaya untuk memperbaiki cara hidup mereka. Bagianbagian ini termasuk: perumpamaan orang kaya yang bodoh (Luk. 12:13-21), perintah untuk menjual harta benda dan bersedekah (Luk. 13:33), perintah untuk mengundang pengemis, dsb. ke perjamuan makan (Luk. 14:12-14), tentang berteman dengan mamon yang tidak jujur (Luk. 16:9), dan kisah orang kaya dan Lazarus (Luk. 16:1931) (Kim, 1998).

Sedangkan bukti adanya orang miskin dalam komunitas Lukas adalah pertama terlihat dalam kisah perumpamaan tentang orang-orang yang berdalih dalam merespons undangan pesta (Luk. 14:15-24). Kedua adalah bagian dari Doa Bapa Kami (Luk. 11:5-13). Doa untuk "memberi kami makanan sehari-hari” (Luk. 11:3) akan diucapkan dengan serius oleh orang miskin di kota Helenistik. Ketiga, Esler menghubungkan idealisme Lukas tentang pangaturan kesejahteraan sosial dalam komunitas Kristen mula-mula di Yerusalem dengan kebutuhan di jemaatnya sendiri bagi anggota yang kaya untuk membantu yang miskin. Lukas telah menggambarkan bahwa gereja mula-mula berhasil melaksanakan sedekah yang Yesus perintahkan kepada orang kaya. Ini muncul dengan sangat jelas dalam kesamaan bahasa dalam Lukas 18:22 dan Kisah Para Rasul 4:34-35 (Kim, 1998).

Pada akhirnya, Esler menekankan bahwa tepat untuk berbicara tentang teologi orang miskin dalam Lukas-Kisah Para Rasul, sebab ia melihat bahwa Lukas memberikan tempat-tempat yang istimewa bagi orang-orang miskin. Pemberitaan perdana Yesus di Nazaret memainkan peranan penting dalam menetapkan prioritas ini (Luk. 4:16-30), namun temanya dimulai lebih awal dalam kata-kata Maria di Magnificat (Luk. 1:52-53), dan dengan kisah kelahiran Yesus di kandang (Luk. 2:7), dan kemampuan orang tua Yesus yang hanya mampu membayar persembahan orang miskin (Luk. 2:24) (Kim, 1998). Lukas lebih banyak menggunakan kata móגıs dari pada $\chi \omega ́$ pa (daerah di luar kota) untuk menggambarkan bahwa Lukas menuliskan tulisannya ini kepada orang-orang Kristen yang berada dalam masyarakat urban yang mengalami penindasan (Kim, 1998).

Esler melihat bahwa Lukas berbicara dalam pengertian literal dan melihat kemiskinan dalam komunitasnya. Tampaknya Lukas memberikan ancaman kepada para elit penguasa yang memiliki kekayaan, yaitu bahwa di masa esktalogis akan ada pembalikan kehidupan antara orang kaya dan orang miskin. Karena itu Esler memaparkan bahwa Lukas memunculkan teologi keselamatan yang berdimensi eskatologis. Pertama, ada perhatian Lukas pada kehidupan setelah kematian di mana orang kaya akan dihukum dan dirampas dari keuntungan yang mereka miliki di bumi, 
sementara mereka yang melarat akan menikmati apa pun yang mereka miliki di dunia ini. Hal ini terlihat dalam kisah orang kaya dan Lazarus (Luk. 16:29-31) dan kisah penjahat yang disalibkan di sebelah Yesus yang dijanjikan Yesus mengenai firdaus (Luk. 23:43). Kedua, Lukas berbicara tentang perumpamaan Perjamuan Besar dengan ucapan Yesus "Berbahagialah dia yang makan roti di Kerajaan Allah" (Luk. 14:15). Ketiga, sementara ketiga Injil Sinoptis melaporkan perkataan Yesus pada Perjamuan Terakhir bahwa ia tidak akan minum anggur lagi sampai ia melakukannya di Kerajaan Allah, hanya Lukas yang mencatat perkataan serupa dengan hormat makan juga (Luk. 22:16). Keempat, Lukas sendiri mencantumkan janji Yesus kepada para murid pada perjamuan malam bahwa mereka akan makan dan minum di mejanya di Kerajaan (Luk. 22:30). Kelima, gambaran tentang Lazarus yang dibawa oleh malaikat ke pangkuan Abraham (Luk. 16:22). Terakhir, janji kepada orang miskin dalam Lukas 1:53 dan 6:21 bahwa mereka akan dipuaskan yang memiliki elemen eskatologis (Esler, 1987).

Akan tetapi, menurut Esler teologi Lukas tentang kemiskinan dan kekayaan ini, tidak hanya berdimensi eskatologi, melainkan juga berdimensi dunia sekarang ini. Penghapusan ketidakadilan, pengentasan penderitaan orang miskin dan orang melarat, bukan hanya realitas eskatologis, tetapi merupakan unsur penting dalam keristenan di dunia ini dan sekarang. Teologi komunitas Kristen berbicara tentang persatuan di dalam Kristus, yang digambarkan dalam satu roti dan satu cawan ekaristi. Salah satu contohnya adalah dalam Lukas 14:12-14. Dalam ayat 12, Yesus memberitahu tuan rumahnya bahwa ketika dia mengadakan pesta atau perjamuan, dia tidak boleh mengundang teman, saudara, kerabat atau tetangga kaya, dengan harapan menerima undangan kembali. Orang-orang yang direkomendasikan Yesus kepada tuan rumah harus diundang adalah pengemis, orang lumpuh, orang cacat dan orang buta (Luk. 14:13). Orang-orang semacam ini tidak akan dapat membayar kembali tuan rumah, tetapi dia akan menerima pembayarannya dalam kebangkitan orang benar (Luk. 14;14). Undangan ini berbeda dengan kebiasaan undangan yang biasa terjadi di masyarakat Helenistik, yang biasanya mengundang orang yang nantinya akan dapat membalas kembali. Jadi, sementara pembalikan total kondisi si kaya dan si miskin tidak akan terjadi hingga dunia berikutnya (secara eskatologis), prosesnya harus dimulai di sini, di bumi. Keselamatan bagi Lukas bukanlah realitas eskatologis, karena dalam komunitas Kristen hal itu dimulai di sini dan saat ini (Esler, 1987). 
Selain itu, ada sejumlah bagian dalam Lukas-Kisah Para Rasul yang menekankan perlunya bersedekah. Hal ini sebagai peringatan yang ditujukan kepada orang Kristen yang kaya untuk membantu yang lebih miskin. Contohnya adalah penguasa kaya dalam Lukas 18:18-23. Kemudian, dalam awal pasal-pasal Kisah Para Rasul, Lukas menggambarkan bagaimana orang-orang percaya yang lebih kaya menjual harta benda mereka dan membagikan kepada mereka yang membutuhkan (Kis. 2:45) atau memberikannya kepada para rasul untuk digunakan bersama (Kis. 4:34-47). Lukas juga mengacu pada fakta bahwa kekayaan cenderung diperoleh secara tidak adil dan karena itu harus didistribusikan kepada orang miskin (Luk. 3:11$14 ; 12: 33 ; 14: 14 ; 16: 9)$. Jika orang kaya tidak membagikan kepada orang miskin, maka mereka akan menghadapi hukuman di kemudian hari. Injil Lukas memaksakan kepada orang kaya suatu persyaratan penting dan bertentangan dengan nilai-nilai sosial masyarakat mereka sendiri. Mereka harus menyediakan makan dan kebutuhan hidup lainnya di dunia ini kepada orang-orang miskin. Jadi, menurut Esler, pemahaman Lukas tentang sikap Kristen yang tepat terhadap kemiskinan dan kekayaan adalah bidang teologinya yang secara signifikan dimotivasi oleh kekuatan sosial dan politik. Dalam hal ini realitas kehidupan kaum miskin di Timur romawi.

\section{Tinjauan Kritis Terhadap Pemikiran Harvey J. Sindima Tentang Teologi Pembebasan Berdasarkan Pemikiran Philip Francis Esler Mengenai Sikap Orang Kaya Terhadap Orang Miskin}

Berikut beberapa hal yang dapat ditinjau mengenai pandangan Sindima tentang Teologi Pembebasan berdasarkan pemikiran Esler. Pertama, berdasarkan uraian Sindima, orang-orang miskin membutuhkan pembebasan dari kemiskinannya sebagaimana yang tertuang dalam konferensi Medellin dan Puebla (Sindima, 2008). Karena itu, Teologi Pembebasan menyuarakan pembebasan bagi orang-orang miskin. Gutiérrez pun mengatakan bahwa gereja adalah untuk orang miskin (Nicokloff, 1993).

Ditinjau dari penelitian Esler, perhatian Teologi Pembebasan terhadap orangorang miskin sesuai dengan perhatian Yesus seperti yang terdapat dalam tulisan Lukas. Esler memperlihatkan bahwa dalam komunitas Lukas juga terdapat orang-orang miskin yang perlu mendapatkan pembebasan. Orang-orang miskin dalam Lukas bukanlah dalam pengertian miskin rohani, melainkan benar-benar miskin secara fisik. Esler melihat bahwa Lukas menunjukkan orang-orang miskin sebagai penerima kabar baik. Hal ini dapat dilihat dalam analisanya terhadap kesempatan pelayanan pertama Yesus berkhotbah di Sinagoge di Nazaret terjadi di bagian awal pelayanan Yesus (Luk. 
4:16-30). Penempatan di bagian awal menggambarkan adanya kepentingan dan prioritas atas orang-orang miskin. Bahkan Esler menyebut Lukas berbicara tentang teologi orang miskin.

Kedua, berdasarkan uraian Sindima, meskipun Teologi Pembebasan menempatkan perhatiannya kepada orang-orang miskin, dan mengupayakan pembebasan bagi mereka, namun Gereja Katolik pada masa itu justru berpihak kepada kelas atas. Hal ini terlihat dari perkataan Sindima yang menyebutkan bahwa "The Chruch backed a semi-feudal system in which the Amerindians became dispossessed of their land and were forced to work for their conquerors." (Sindima, 2008). Gereja Katolik tidak memihak orang-orang miskin, tetapi kepada penindas (Grenz \& Olson, 1992). Ternyata komunitas gereja yang menggambarkan komunitas Kristen di mana Teologi Pembebasan berkembang, tidak menunjukkan fungsinya dengan baik dalam rangka untuk ikut mewujudkan pembebasan bagi orang-orang miskin.

Berdasakan penelitian Esler, tentunya konteks sosial yang terjadi di mana Teologi Pembebasan ini berkembang memiliki perbedaan dengan teologi Lukas. Teologi Lukas berbicara tentang persatuan di dalam Kristus. Persatuan ini tergambarkan dengan adanya keterlibatan orang-orang kaya terhadap orang-orang miskin. Contohnya, seperti dalam awal pasal-pasal Kisah Para Rasul, Lukas menggambarkan bagaimana kehidupan orang Kristen yang lebih kaya dalam menjalankan perintah Yesus untuk menjual harta mereka dan membagikannya kepada yang membutuhkan (Kis. 2:45).

Apa yang dikatakan oleh Esler tentang Lukas memberikan suatu gambaran cara hidup komunitas Kristen dapat diafirmasi. Di dalam komunitas ini menunjukkan adanya persekutuan yang erat. Persekutuan tersebut ditunjukkan dengan adanya kepedulian mereka sampai pada soal kebutuhan materi. Hal ini dapat dilihat dalam Kisah Para Rasul 2:42-47. Persekutuan dalam teks ini juga memperlihatkan adanya persamaan dan kesetaraan yang ditujukkan dengan kata hapanta koina (ayat 44) (Hananti, 2021). Melalui teks ini dapat diketahui bahwa kekayaan memampukan mereka untuk memperkuat persekutuan dan dapat mengatasi kesenjangan.

Ketiga, menurut Sindima, sebenarnya kemiskinan di Amerika Latin tidak hanya pada masalah ekonomi, melainkan juga soal masyarakat pribumi, ras, keterasingan budaya dan perempuan yang erat kaitannya dengan konteks sosial di Amerika Latin. Akan tetapi, Teologi Pembebasan di tahun 1980-an dan 1990-an hanya memberikan perhatian kemiskinan dalam hal ekonomi. 
Di masyarakat Amerika Latin terdapat stratifikasi sosial (1980-an). Orang-orang Amerindian adalah masyarakat pribumi Amerika Latin, yang merupakan kelas paling bawah dalam struktur masyarakat beserta dengan orang keturunan Afrika. Sindima menyebut bahwa dalam banyak hal masyarakat pribumi adalah orang-orang yang tidak terlihat. Artinya, keberadaan masyarakat pribumi ini tidak dianggap oleh kelas atas (orang-orang Spanyol).

Situasi sosial di Amerika Latin digambarkan oleh Sindima dengan mengatakan bahwa masyarakat Amerindian mengalami keterasingan dalam hal ras. Keterasingan ini misalnya dalam hal kepemilikan tanah. Masyarakat Amerindian sebagai masyarakat pribumi semestinya memiliki tanah, namun kenyataannya mereka tidak memiliki kuasa atas tanah tersebut. Namun, justru mereka diperbudak. Selain itu, di pemerintahan, orang-orang kulit hitam juga tidak mempunyai tempat untuk menduduki pemerintahan. Lebih lagi, di dunia pendidikan, orang-orang kulit hitam tidak mendapatkan hak yang sama untuk memperoleh pendidikan seperti orang-orang kulit putih. Situasi tersebut menggambarkan adanya stratifikasi sosial dalam masyarakat Amerika Latin yang memperlihatkan adanya jurang pemisah antara yang kaya dan yang miskin. Yang miskin tidak hanya mengalami penderitaan soal ekonomi, tetapi juga soal ras sehingga tidak mendapatkan tempat yang layak dalam masyarakat.

Selain keterasingan dalam hal ras, Sindima juga mengemukakan bahwa orangorang miskin di Amerika Latin juga mengalami penindasan keterasingan budaya. Menurutnya, keterasingan budaya ini juga tidak banyak mendapat perhatian dalam Teologi Pembebasan. Hal ini berkaitan dengan idologi Marxis yang sangat mempengaruhi Teologi Pembebasan, sehingga menyebabkan identitas etnis dari ras minoritas tidak tercermin dalam teologi. Pada akhirnya terlihat bahwa kapitalis borjuis menghasilkan mentalitas dan gaya hidup borjuis. Yang kaya akan semakin kaya, dan yang miskin akan semakin miskin.

Situasi sosial-budaya juga tergambarkan dalam komunitas Lukas. Dalam penelitian Esler, terdapat stratifikasi sosial dalam komunitas Lukas. Komunitas Lukas berada pada realitas kehidupan kota Helenistik di Romawi Timur menjelang akhir abad pertama Masehi. Strata sosial tersebut ada dalam masyarakat Romawi. Orang-orang yang ada pada strata atas adalah para elit bangsawan dan elit kaya. Sedangkan strata bawah adalah orang-orang miskin yang terdiri dari pedagang, pengrajin, pekerja harian, orang yang cacat fisik dan para budak. Stratifikasi sosial dalam masyarakat Romawi ini juga menggambarkan bahwa kemiskinan tidak hanya soal ekonomi, tetapi juga soal sosial-budaya. 
Secara sosial, orang-orang miskin berada dalam penindasan. Mereka mengalami keterasingan dari orang-orang yang berada pada strata atas. Pemaparan Esler menyatakan bahwa di kota-kota Helenistik tidak pernah terjadi orang-orang yang berada dalam strata atas dan bawah berkumpul bersama dalam suatu persekutuan. Orang-orang dalam strata atas akan berkumpul bersama dengan orang-orang dalam strata yang sama, demikian juga dengan orang-orang dalam strata bawah. Kebiasaan yang demikian menjadi perhatian yang serius bagi Lukas. Hal ini terbukti dari bahannya yang mamasukkan cerita tentang perkataan Yesus mengenai siapa yang harus diundang (Luk. 14:12-14). Dalam budaya masyarakat Helenistik, biasanya undangan perjamuan akan diberikan kepada orang-orang yang berpotensi dapat membalas undangan kembali. Namun ayat 13 , Yesus merekomendasi siapa saja yang harus diundang, yaitu pengemis, orang lumpuh, orang cacat dan orang buta, sebab orangorang semacam ini tidak berpotensi untuk dapat membalas udangan. Hal ini memperlihatkan bahwa sebenarnya komunitas Kristen yang ideal merupakan komunitas persekutuan yang tidak dibatasi oleh stratifikasi sosial.

Selain itu, keterasingan dalam hal ras diperlihatkan oleh Esler mengenai distribusi jagung yang dilakukan oleh masyarakat Roma. Orang-orang yang berhak mendapatkan distribusi ini hanyalah penduduk Romawi. Sedangkan orang-orang di luar dari penduduk Roma tidak bisa memperoleh distribusi jagung yang dibagikan secara gratis tersebut.

Dengan demikian dapat disimpulkan bahwa tinjauan Sindima terhadap penindasan orang-orang miskin yang tidak hanya soal ekonomi juga terdapat dalam komunitas Lukas. Kemiskinan dalam komunitas Lukas juga tidak hanya soal ekonomi, tetapi juga soal keterasingan rasisme dan budaya. Karena persoalan ini, penulis melihat bahwa penyelesaian kemiskinan yang ditunjukkan oleh Lukas juga mencakup spektrum ras dan budaya. Sebagai contohnya adalah Lukas 7:1-10 yang menceritakan tentang Yesus menyembuhkan hamba seorang perwira di Kapernaum. Perwira ini kemungkinan adalah seorang penduduk Roma, sebab ia memakai gelar perwira (erkatontarchos) yang menggambarkan sorang militer tentara Roma (Fitzmayer, 1985).

Tokoh kedua adalah seorang hamba yang bekerja sebagai hamba di rumah seorang perwira tersebut. Di ayat 2,3, dan 10 digunakan kata doulos untuk menyebut hamba. Sedangkan di ayat 7 digunakan kata pais untuk menyebut hamba dengan menunjuk seorang yang sama (Galih, 2017). Hamba tersebut tidak mungkin jikalau dia adalah seorang warga Roma. Tidak mungkin warga Roma bekerja sebagai hamba. Melalui kedua tokoh ini, dapat dimengerti bahwa Lukas berupaya untuk menghapus 
keterasingan ras dan budaya dalam komunitasnya. Seorang perwira dan hamba ini menggambarkan dua ras atau budaya yang berbeda, namun dapat menggambarkan persatuan.

Keempat, pada dasarnya Teologi Pembebasan telah menyuarakan pembebasan bagi orang-orang miskin. Namun, Teologi Pembebaskan menekankan bahwa orang-orang miskin harus memiliki martabat, sebab mereka adalah agen sejarah pembebasan mereka sendiri. Hal ini mengandung pengertian bahwa orangorang miskin disuarakan untuk tetap dapat terus berjuang melawan penderitaan yang harus mereka alami. Teologi Pembebasan tidak menyuarakan tentang bagaimana orang-orang kaya (strata atas) dapat berpengaruh atau memiliki peran dalam pembebasan orang miskin.

Lukas juga memperlihatkan stratifikasi sosial dalam komunitasnya. Namun, Lukas tidak hanya menyuarakan tentang pembebasan kepada orang miskin agar dirinya dapat berjuang atas penderitaan yang dialaminya. Lukas menyuarakan pembebasan orang miskin ini juga kepada orang-orang yang berada dalam stratas sosial atas atau orang kaya. Artinya, Lukas ingin melibatkan orang-orang strata atas untuk menjadi bagian bagi orang miskin.

Esler mengungkapkan bahwa teologi Lukas tentang keselamatan tidak hanya berdimensi eskatologis, melainkan juga memiliki dimensi sekarang ini di dunia ini. Karena itu, dalam membangun teologinya ini, Lukas melibatkan orang kaya untuk mewujudkan pembebasan bagi orang miskin dalam masa sekarang ini di dunia ini.

Keterlibatan orang-orang kaya kepada orang-orang miskin dalam upaya pembebasan kemiskinan terlihat pada penekanan sedekah. Peringatan akan sedekah secara khusus ditujukan kepada orang Kristen kaya agar dapat membantu orang miskin. Esler melihat bahwa Lukas tampaknya mengacu bahwa kekayaan cenderung diperoleh secara tidak adil. Karena itu, kekayaan harus dibagikan kepada orang miskin. Hal ini dapat dilihat dalam Lukas $3: 11-14 ; 12: 33 ; 14: 14 ; 16: 9$. Penekanan Lukas terhadap komunitasnya yang kaya ini berbeda dengan kebiasaan di lingkungan Helenistik. Dalam Lingkungan Helenistik biasanya orang kaya tidak pernah memperlakukan bawahannya dengan adil. Namun, Lukas menginginkan adanya keterlibatan orang kaya dalam mewujudnyatakan pembebasan bagi orang miskin dalam dimensi sekarang di dunia ini.

Dalam penelitian Esler, hal sedekah tampak dalam Lukas 18:22 dan Kisah Para Rasul 4:34-35. Menurut Esler, Lukas berhasil menggambarkan bahwa gereja mulamula melaksanakan perintah untuk memberikan sedekah. Menurutnya, di antara kedua 
teks ini ada kesamaan bahasa, yaitu mengenai menjual harta dan memberikannya kepada orang miskin.

Memang benar dengan apa yang dipaparkan oleh Esler mengenai kedua teks ini yang berkaitan dengan keterlibatan orang kaya untuk membantu orang miskin. Misalnya, dalam Lukas 18:22 merupakan bagian yang penting dalam cerita perumpamaan orang kaya sukar masuk Kerajaan Allah. Di ayat ini disebutkan tentang panta hosa echeis (menjual segala yang dimilikinya) dan diados (mendistribusikannya ulang). Distribusi ulang berarti menyalurkan harta milik. Yang dimaksud dalam ayat ini adalah menyalurkan harta milik kepada orang miskin. Menjual harta dan menyalurkannya kepada orang miskin adalah perintah Tuhan yang berkaitan dengan sesama, sebab di Imamat 19:18 memuat tentang perintah ini, serta dalam Imamat 25 memuat tentang menyalurkan harta kepada orang miskin. Jadi, teks ini merupakan salah satu gambaran perlunya keterlibatan orang kaya kepada orang miskin, yang sebenarnya sudah menjadi perintah Allah.

Namun sayangnya, dalam menekankan dimensi dunia sekarang ini dalam konsep keselamatan Lukas, Esler kurang memperhatikan peranan Roh Kudus. Padahal peran Roh Kudus dalam Lukas sangat menonjol dalam tulisan Lukas. Perlu dipahami terlebih dahulu bahwa arti berbagi yang digambarkan dalam Kisah Para Rasul harus dilihat bahwa komunitas Kristen mula-mula ditembus oleh kuasa Roh Kudus. Karena itu, dalam penantian parousia, keselamatan yang hadir sekarang ini ditandai dengan kehadiran Roh Kudus, bahkan sampai pada hal harta benda. Jadi, keselamatan yang dinyatakan pada masa sekarang dalam dunia ini adalah dalam pemeliharaan Tuhan melalui harta benda. Karena itu, Lukas menekankan bahwa harta benda harus dapat dipakai untuk mewujudkan sisi soterologis Allah pada masa kini dalam suatu komunitas bersama.

\section{KESIMPULAN}

Dalam pemikiran Sindima, kemiskinan tidak hanya menyangkut soal ekonomi, melainkan juga menyangkut keterasingan orang-orang miskin atas ras dan budaya. Berdasarkan evaluasi Sindima, Teologi Pembebasan tidak menggambarkan adanya hubungan antara orang kaya dengan orang miskin. Teologi Pembebasan dalam pandangan Sindima, tidak menggambarkan relasi antar manusia yang merupakan cerminan dari relasi dengan Allah. Pada masa kononial, Gereja Katolik yang merupakan gambaran komunitas orang percaya tidak dapat menunjukkan relasi ini. Selain itu, Teologi Pembebasan juga memberikan penekanan agar orang-orang yang 
mengalami kemiskinan itu berupaya sendiri untuk dapat bertahan dalam penderitaannya, sebab mereka sendiri adalah agen sejarah pembebasan. Pada kenyataannya di tengah-tengah masyarakat memang ada stratifikasi sosial yang memungkinkan adanya jurang pemisah, seperti antara orang kaya dan orang miskin, atau antara kelompok ras tertentu. Namun, dalam teologi Kristen semestinya jurang tersebut tidak dibuat lebar, melainkan sebisa mungkin dijembatani.

Dalam komunitas Lukas juga terdapat jurang pemisah antara yang kaya dan yang miskin. Karena itu, teologi Lukas memberikan usulan terhadap upaya untuk mengatasi jurang tersebut. Usulan Lukas untuk mengatasi jurang tersebut adalah dengan memperlihatkan adanya komunitas berbagi dalam bahan tulisannya. Lukas menekankan adanya keterlibatan orang-orang kaya dalam rangka mengatasi kemiskinan yang dialami oleh orang-orang miskin di jemaat mula-mula. Jadi, teologi Lukas berdasarkan Esler dapat menjadi wawasan teologis dalam menghadapi masalah kemiskinan dengan menghubungkan kedua spektrum kelas, yaitu orang kaya dan orang miskin. Dengan demikian, orang miskin tidak hanya berupaya sendiri dalam menghadapi kemiskinanannya, melainkan juga ada keterlibatan orang kaya.

\section{DAFTAR PUSTAKA}

Berghoef, G., \& DeKoster, L. (1984). Liberation Theology: The Church's Future Shock. Christian's Theology.

Esler, P. F. (1987). Community and Gospel in Luke-Acts: The Social Motivations of Lucan Theology. Cambridge University Press.

Fitzmayer, J. (1985). The Gospel According to Luke: Introduction, Translation, and Notes. Doubleday.

Galih, A. W. (2017). Universalism Aspect of Double Delegation in Luke 7:1-10.

Orientasi Baru, 26(2).

Grenz, S. J., \& Olson, R. O. (1992). 20th-Century Theology: God \& The World in a Transitional Age. Inter Varsity Press.

Gumelar, F., \& Wijaya, H. (2019). Peran Gereja Masa Kini Menyikapi Teologi Pembebasan Gutierrez. BIA: Jurnal Teologi Dan Pendidikan Agama Kristen, 2(2).

Hananti, V. (2021). Kontribusi Teologi Kepemilikan dan Fungsi Kekayaan Menurut Lukas bagi Upaya Pengentasan Kemiskinan di Indonesia. IMMANUEL: Jurnal Teologi Dan Pendidikan Kristen, 2(1).

Kim, K.-J. (1998). Stewardship and Almsgiving in Luke's Theology. Sheffield 
Academic Press.

Kothari, C. (2004). Research Methodology: Methods and Techniques. New Age International Limited Publisher.

Kriswanto, A. (2020). Melampui Eksegesis dan Eisegesis: Tinjauan Terhadap

Hermeneutika Teologi Pembebasan. IMMANUEL: Jurnal Teologi Dan

Pendidikan Kristen, 1(2).

Mali, M. (2016). Gutierrez dan Teologi Pembebasan. Orientasi Baru, 25(1).

Natali. (2000). Evaluasi Kritis Terhadap Doktrin Gereja dari Teologi Pembebasan. VARIETAS: Jurnal Teologi Dan Pelayanan, 1(2).

Nicokloff, J. (1993). Church of the Poor: The Ecclesiology of Gustavo Gutiérrez. Journal Theological Studies, 54(1).

Schwarz, H. (2005). Theology In A Global Context The Last Two Handred Years. WB Eerdmans.

Sindima, H. J. (2008). The Gospel According To The Marginalized. Peter Lang.

Uchegbue, C. O. (2011). The Hermeneutics of Liberation Theology: A Critical Look At Its Christological, Harmatiological, Soteriological Dimentions. Lumina, 22(1).

Vegel, Z. (2018). Liberation Theology: A Critical Analysis. Kairos - Evangelical Journal of Theology, 12(1).

Yewangoe, A. A. (1995). Implikasi Teologi Pembebasan Amerika Latin Terhadap Misiologi dalam Mengupayakan Misi Gereja Yang Kontekstual (J. C. Nelson (ed.)). PERSETIA. 